\title{
GOLPE MILITAR: \\ DESAFIOS ENTRE O MARCO DE MEMÓRIA E O MUNDO DOS TRABALHADORES ${ }^{1}$
}

\section{Paulo Cesar Inácio²}

RESUMO: A reflexão que permitiu identificar em disputas sociais a existência de muitas memórias necessita ser acompanhada de "outras histórias", a afirmação nos alerta para o risco de processos sociais instituídos como marcos possibilitarem a formação de memórias que, aparentemente resultantes do marco que descreve, na verdade o constroem, tendo como consequência o apagamento de memórias alternativas, geralmente situadas no mundo dos trabalhadores. No artigo exploramos o desafio de passar do reconhecimento das muitas memórias a outras histórias testando estas indagações no golpe civil/militar ocorrido em 1964. Se na década de 1960, os desafios da construção do socialismo e as maneiras como se processaria uma revolução no Brasil mobilizam a esquerda e tencionam posições de Partidos como o PCB, no seio da própria esquerda esse tom vai se esvaindo, passando a frisar, no início da década de 80 , a violência

1 Expresso minha gratidão aos colegas que, de maneira formal e informal, têm alicerçado meu percurso na construção de leituras e reflexões. Destaco os professores da linha Trabalho e Movimentos Sociais do Programa de PósGraduação em História da Unioeste, Campus Marechal Cândido Rondon, Rinaldo José Varussa, Antônio de Pádua Bosi e Wagner José Moreira; da linha Trabalho e Movimentos Sociais do programa de Pós-Graduação em História da Universidade Federal de Uberlândia, Sérgio Paulo Morais e Paulo Roberto de Almeida; minha esposa, Fátima Pacheco de Santana Inácio; os companheiros de trabalho e de reflexão, Luiz Carlos do Carmo, Luzia Márcia Resende Silva e Cláudio Lopes Maia; e em especial Yara Aun Khoury, pela influência na formação intelectual e humana, e nossa saudosa Déa Ribeiro Fenelon, pelas tantas lições e desafios.

2 Doutor em História Social; professor da Universidade Federal de Goiás, Regional Catalão, Unidade Acadêmica Especial de História e Ciências Sociais; professor do Programa de Pós-Graduação em História, UFG/Regional Catalão. 
do Estado e a necessidade do restabelecimento das garantias democráticas. Ao ser edificado como acontecimento, essa memória oculta a própria redefinição interna dos seus termos, inclusive a concepção de Estado. A construção e perpetuação dessa memória tem provocado um apagamento de outras experiências vivenciadas e significadas no mundo dos trabalhadores. Explorando as reflexões de autores como Alessandro Portelli e Yara Aun Khoury identificamos a experiência do golpe em trabalhadores do Sudeste Goiano, avançando na perspectiva do direito à memória.

PALAVRAS-CHAVE: Memórias. Golpe civil militar. Trabalhadores.

ABSTRACT: The reflection that allowed to identify in social disputes the existence of many memories needs to be accompanied by other histories, the statement alerts us to the risk of social processes instituted as milestones to enable the formation of memories that seemingly Resulting from the milestone it describes, actually construct it, resulting in the erasure of alternative memories, usually located in the world of the workers. In the article, we explored the challenge of moving from recognizing the many memories to other stories by testing these questions in the civil / military coup in 1964. If in the 1960s the challenges of building socialism and the ways in which a revolution in Brazil would take place mobilized the left and intend positions of parties like the PCB, within the own left that tone is disappearing, beginning to emphasize, in the early 80 's, the violence of the state and the need to reinstate democratic guarantees. When it is constructed as an event, this memory hides the very internal redefinition of its terms, including the conception of the State. The construction and perpetuation of this memory has caused a blurring of other experiences experienced and meaningful in the world of the workers. Exploring the reflections of authors such as Alessandro Portelli and Yara Ahun Khoury, we identify the experience of the coup in workers from the Southeast of Goiânia, advancing from the perspective of the right to memory.

KEYWORDS: Memories. Civil military coup. Workers. 
Inicio este texto abordando o golpe militar ocorrido no Brasil de uma maneira não usual. Tendo nascido em 1965, um ano depois do golpe que deu início à ditadura militar no Brasil, pelos limites da idade, não tenho lembranças pessoais do evento, mas cresci no ambiente social em que ela se dava. Não ter lembranças pessoais diretamente ligadas ao governo dos militares se deve, por um lado, ao não envolvimento de nenhum familiar com a militância política e, por outro, ao fato de o golpe e o governo dos militares se encaixarem no quebra-cabeças das vivências de famílias de trabalhadores pobres. A ação do Estado era gerenciar uma violência que se enraizava na base social, onde a precariedade material, a espoliação, o saque e o butim do que era público não foi estranha ao mundo dos trabalhadores. Mundo esse tão desigual e violento que só pode ser mantido por um Estado revestido dos mesmos atributos do mundo que o constrói. Para trabalhadores e pobres esse Estado não começou a funcionar em 1964 e sua ação ainda não terminou.

Localizo minha primeira recordação no início da década de 1970. Eu devia ter entre 8 e 9 anos de idade. Foi na pequena cidade de Três Ranchos, interior de Goiás. Tendo meu pai sido transferido como feitor da Rede Ferroviária Federal S/A de Goiandira para aquela cidade, entramos, ele e eu, no bar do Godofredo para comprar algo. No interior do estabelecimento interessei-me por um doce, pedi então que me comprasse um pedaço, mas meu pai argumentou que não tinha dinheiro. Chateado por não ganhar o doce e enraivecido com o dinheiro que representava uma barreira que me separava do meu desejo, disse que então ele não deveria existir.

Fui repreendido pelo meu pai, que se aproximou e falou em voz baixa algo parecido: "não fala isso, isso é coisa de comunista, eles querem acabar com o dinheiro, se a polícia escutar isso ela te prende". Assim, fiquei achando estranho o tal comunismo, mas no geral gostei de saber que havia outras pessoas que pensavam como eu, não falei mais em acabar com o dinheiro, afinal não queria ser preso pela polícia, mas o desejo de comer o doce permaneceu. 
Já na vida acadêmica, no período em que cursava o mestrado ${ }^{3}$, ao realizar uma entrevista com o Sr. Altivo Marques ${ }^{4}-$ sendo o $^{-}$ interesse da pesquisa saber como a chegada da ferrovia havia tensionado a sociedade da época em um determinado momento desviei o assunto para o golpe militar e como este atingiu a cidade de Goiandira, visto que havia um esforço do Partido Comunista para identificar na cidade o foco de uma célula do partido que teria sido violentamente combatida. Nesse momento ocorreu-me algo interessante. A esposa do entrevistado, dona Alfa, que estava presente, interrompeu a conversa dizendo que havia um dentista na cidade de cujo nome ela não se lembrava, mas que era um comunista atuante.

Indaguei como ela sabia que ele era comunista e o que ele fazia na cidade que indicava ser pertencente ao partido. Ela então me respondeu com voz baixa que estava fazendo tratamento dentário com ele e que, durante o tratamento, ao deixar cair a prótese no chão e perceber que ela havia ficado presa no assoalho, o dentista dissera: "desgraça". Fiquei aguardando o desenlace da entrevista, mas depois de alguns segundos entendi que a narrativa tinha acabado. A grande atitude rebelde do dentista tinha sido gritar: "desgraça".

A identidade do comunista teria sido revelada não em virtude de sua militância política, mas em razão do uso de um vocabulário que destoava e ameaçava o mundo profundamente religioso em que essa senhora havia sido criada e os valores que professava/professa.

Em Três Ranchos, cidade do Sudeste Goiano recomponho na minha vivência de criança que, qualquer atitude, palavra ou gesto que ameaçasse os valores e costumes tradicionais era identificado como comunista. Assim, elaborei o comunismo não como um conjunto orgânico de ideias ou uma estratégia de

3 INÁCIO, Paulo Cesar. Trabalho, Ferrovia e Memória: a experiência de Turmeiro (a) no trabalho ferroviário. 2009. 2003. 128 f. Dissertação (Mestrado em História Social)-Programa de Pós-Graduação em História, Universidade Federal de Uberlândia, Uberlândia, 2003.

4 Entrevista com o Sr. Altivo Marques da Silva, em 26 de julho de 2001. 
ação de partidos comunistas, mas o identifiquei com as coisas quotidianas da vida. Os comunistas me eram apresentados como homens que usavam cabelos compridos e barba, fumavam maconha, xingavam, desobedeciam aos pais, não iam à Igreja e se separavam das esposas. Os militares não eram vistos como personagens que me salvariam dos comunistas; era improvável que cortassem cabelos, aparassem a barba das pessoas, proibissem xingamentos, obrigassem pessoas a irem à Igreja ou que mantivessem casais unidos. Eles eram apresentados como o novo grupo que assumia o Estado, assim como os outros grupos que os antecederam, podendo prender e soltar qualquer pessoa. Eram novos gerentes para uma velha tarefa: manter um mundo desigual e desumano em funcionamento, firmando e reafirmando $o$ controle e a violência contra, inclusive, o mundo dos trabalhadores.

A argumentação que colocamos nesta intervenção objetiva identificar como a constituição do golpe militar de 1964, abordado como ordenação do acontecimento, oculta os desafios, inclusive da esquerda, em incorporar nesta memória, as tensões de outras temporalidades. Esse refazer oculta as redefinições internas que a esquerda experimenta. No mesmo caminho, como esse processo, ao se sobrepor a outras memórias possíveis, neste caso, ao que os trabalhadores do Sudeste Goiano vivenciaram e elaboraram, permite que este campo de memória seja apropriado por outros projetos inclusive de direita.

Em 2014, celebraram-se os 50 anos do golpe militar. Ao golpe se seguiu uma ditadura civil/militar, e o relembrar ensejou a ida para aquele período na busca dos significados de tal processo para o Brasil contemporâneo. Diversas publicações ${ }^{5}$ apresentaram dossiês cujo foco central foi publicizar reflexões revelando os significados do golpe de 1964.

5 TEMPOS HISTÓRICOS. Marechal Cândido Rondon: EDUNIOESTE/PR, v. 18, n. 1, 2014. Disponível em: <http://e-revista.unioeste.br/index.php/ temposhistoricos/issue/view/683/showToc $>$. Acesso em: 10 out. 2015; CADERNOS DE HISTÓRIA. Belo Horizonte: PUC Minas, v. 15, n. 22, 2014. Disponível em: <http://periodicos.pucminas.br/index.php/cadernoshistorial issue/view/508/showToc $>$. Acesso em: 19 out. 2015. 
Nas publicações, é reiterado o mote geral de como o tema sem sido abordado: 01 - reafirma-se o ocorrido, redimensionando sua importância pela descoberta/denúncias de aspectos que alargam o mesmo fato; 02 - Elege-se os grupos militares e militantes de esquerda como únicos protagonistas.

Nesse aspecto entendemos que, ao aprisionar o que deve ser lembrado em um tempo, 1964/1985, restringe-se o lembrado a um tempo, desprezando pressões e intencionalidades que pressionaram parte da esquerda a reafirmar/mudar suas posições em outras temporalidades.

Ao ser constituído como marco de memória, apartado de outras temporalidades, tem sido reconstruído com um cunho pedagógico, alertando-nos para o fato de que a reprodução de alguns componentes que se observaram naquele período reprisaria o próprio ocorrido. Em alguns momentos celebrativos tem-se atualizado sua leitura como alerta para o presente.

No ano de 1994, na celebração dos 30 anos do golpe, numa conjuntura em que o primeiro presidente eleito pelo voto da população, Fernando Collor de Melo, foi cassado, a evocação do fato alicerça uma memória de aprendizado circunscrita no tempo e em seus protagonistas, enquadrando o período da recordação.

Paul Singer produz uma análise que alerta para o fato de que fatores econômicos experimentados em 1994 poderiam ser ligados ao que se experimentava em 1964. Essa ligação seria indutora de um reprisar do golpe como solução política executada em 1964:

A crise econômica de 1964 é muito semelhante, quanto a seu aspecto de impasse, à longuíssima crise de 1981 até agora. A crise de 64 foi resolvida à força pelos militares. Os trabalhadores foram efetivamente submetidos, a rebeldia operária foi fortemente reprimida (não houve mais greves), a rebeldia camponesa liquidada com repressão selvagem, a rebeldia estudantil também foi reprimida; como reação, em 1969 70-71, a oposição, dispersa em muitos grupos, foi à luta armada. (SINGER, 1997, p. 20). 
Comparando a experiência interrompida com o golpe em 1964 com um período de democracia autêntica hipoteticamente vivido em todo o Brasil, o autor aponta no acontecimento conjunturas econômicas e sociais da época, alertando para o fato de que condições econômicas semelhantes poderiam desencadear 0 mesmo evento em 1994.

No ano 2014, em um instante que o Brasil é governado por um partido de esquerda, que parte do grupo que foi perseguido em 1964 está no poder, a tônica da lembrança é no caminho de aprofundar no conhecimento do passado. Pode-se observar essa dinâmica no dossiê " 50 anos do Golpe de 1964", organizado pela revista Tempos Históricos, que enriquece o ocorrido com observações como a participação de instituições civis na construção do golpe.

O dossiê, já na introdução, perpetua uma interpretação do passado no passado. Assim, os editores apresentam o campo de forças em que se vão mover as diversas contribuições.

Este dossiê organizado por Tempos Históricos parte exatamente da convicção de que o Golpe de 1964, muito mais do que ter provocado uma troca de guarda entre representantes de interesses burgueses, significou a consumação da crise do regime de dominação classista fundado na Constituição de 1946 e a abertura de um novo momento histórico, em que se implantaram estruturas típicas de uma ditadura empresarial militar de vocação contrarrevolucionária permanente, com estrutura de poder apropriada para a consolidação da passagem a um novo modelo de acumulação capitalista, em uma perspectiva de desenvolvimento associado dependente. (CALIL; LEMOS, 2014, p. 10).

Ao destacar na reflexão aspectos como dominação classista, atitude contrarrevolucionária e desenvolvimento dependente enquanto firmemente ancorados no Estado, abre-se um guardachuva tão amplo que poderia estar devidamente coberto desde 1822, com a independência, até 2015, com o governo da presidenta Dilma Roussef. Poderíamos sem problemas levar 
a interpretação para o período colonial, atribuindo ao Estado português, gestor da colônia, os mesmos atributos.

Estando formado o ano de 1964 como marco de memória, enclausurado em um tempo e em instituições, torna-se esse um objeto que pode ser comparado a um paciente imobilizado na maca do tempo e na interpretação e ação das instituições, passando para o percurso de sua dissecação exaustiva, como se a bucha que o escova ou o bisturi que o disseca sempre permitisse uma novidade que o reafirme e não o delegue ao esquecimento.

Em uma de suas intervenções, Melo e Hoelever (2014) recompõem, na obra de René Dreyfus, 1964: a conquista do Estado, uma busca de aprimoramento de conceitos e o tratamento adequado para o fato passado, destacando a participação de instituições civis no golpe.

Estes artigos dão a tônica de como o marco de memória tem sido tratado, num esforço para dissecar o ocorrido indicando aspectos que ainda não teriam sido abordados (ou adequadamente abordados), neste caso, a participação de setores empresariais civis no golpe, dentre outros.

A disputa pelas memórias tem se dado, via de regra, na identificação do fato, do acontecimento de onde se deriva o que deve ser lembrado. Purificar o fato de toda a maculação ou esclarecer as minúcias do que teria ocorrido, o que representa parte importante do processo, tem resultado numa memória legítima de condenação à violência e aos crimes praticados.

Contudo, Khoury nos alerta para como alguns fatos, ao se instituírem, consagram memórias poderosas:

Por esse caminho, vamos ampliando uma reflexão, já em curso no campo da história, sobre os modos como lidamos mais facilmente com determinados fatos instituídos como históricos, em detrimento de outros, que têm um significado profundo para determinados sujeitos e para determinadas culturas, mas que vão sendo ignorados ou ocultados sob o peso de histórias, memórias mais poderosas. Além disso, a narrativa oral, como gênero específico de discurso, impregnado de interrupções, digressões, repetições, correções, 
constituindo-se mais como um processo do que como um texto acabado, põe em evidência o movimento da palavra, da memória e da consciência, demandando um tratamento específico, que também pode ser bem proveitoso no sentido de ampliar e modificar a noção de fato histórico e, por esse caminho, contribuir para a incorporação de outros sujeitos à história. (KHOURY, 2001, p. 85).

Memórias poderosas que constroem o marco têm se esforçado, no presente, como fatos e portadoras de uma verdade interna. Os que buscam a verdade pretendem apenas validá-la como verdade, escapando à questão se esse encaminhamento dará ao presente uma direção melhor.

Esse percurso foi reafirmado em 18 de setembro de 2011, com a Lei n. 12.528, que criou a Comissão Nacional da Verdade. Essa comissão, ramificada nos estados em comissões regionais, procederam a uma dissecação do acontecimento com a convicção de que a identificação dos crimes e de sua autoria, criando uma memória purificada da mentira, livrar-nos-ia da repetição do ocorrido.

Evidencia-se o caráter da descoberta da verdade nos dois primeiros capítulos da lei.

Art. 1o - É criada, no âmbito da Casa Civil da Presidência da República, a Comissão Nacional da Verdade, com a finalidade de examinar e esclarecer as graves violações de direitos humanos praticadas no período fixado no art. $8^{\circ}$ do Ato das Disposições Constitucionais Transitórias, a fim de efetivar o direito à memória e à verdade histórica e promover a reconciliação nacional.

Art. 2o - A Comissão Nacional da Verdade, composta de forma pluralista, será integrada por 7 (sete) membros, designados pelo Presidente da República, dentre brasileiros, de reconhecida idoneidade e conduta ética, identificados com a defesa da democracia e da institucionalidade constitucional, bem como com o respeito aos direitos humanos.

$\S 1$ 으 - Não poderão participar da Comissão Nacional da Verdade aqueles que: 
I - exerçam cargos executivos em agremiação partidária, com exceção daqueles de natureza honorária;

II - não tenham condições de atuar com imparcialidade no exercício das competências da Comissão;

III - estejam no exercício de cargo em comissão ou função de confiança em quaisquer esferas do poder público. (BRASIL, 2011).

A lei recua a investigação para a década de 1940, quando o Partido Comunista foi posto na ilegalidade.

Reconhecendo a importância do governo em esclarecer a ação do Estado em um período de muitas mortes e perseguições, essa intervenção traz em si as contradições de ser do Estado, frisando a verdade como possível de proceder à reconciliação nacional, atribuição exigida dos integrantes da comissão pautados pela neutralidade. É inegável que para nós, historiadores, verdade e neutralidade trazem desafios que questionam a própria validade da história.

A busca pela verdade, patrocinada, ordenada legalmente e financiada pelo Estado traz em si, de maneira inerente, as condições de uma instância que é hegemonizada pelo capitalismo, cuja ação, em 1964, se baseava justamente na ameaça a esse sistema. O Estado que interveio em 1964 institucionalizando a violência como recurso de defesa contra a ameaça comunista se refaz em sua ação e, com novos gerentes, se propõe a rever suas ações, reduzindo toda revisão histórica a indenizações aos que sofreram sua violência.

Contudo, o imenso respeito às dores e perdas das famílias é necessário, inclusive para permitir avanços, que questionemos o papel do Estado Brasileiro, que forjou e deu suporte às violências cometidas, agora repare às violências cometidas. Reparar financeiramente às famílias, pela morte dos combatentes, provoca o esquecimento do por que lutavam. Para muitos dos que foram mortos o mote da luta era justamente a destruição deste Estado.

O processo de indenizações é parte de um processo amplo e complexo em que os termos da memória, reportando ao mesmo acontecimento, altera profundamente os termos de sua 
constituição inicial. Combatentes como: Carlos Marighella, Carlos Lamarca, Margarida Maria Alves, Santo Dias da Silva e outros deveriam constar no altar da história por terem sacrificado sua própria vida a enfrentar, denunciar e lutar contra um sistema que legitima a espoliação diária dos pobres, relegando-os a uma vida miserável. Esse comprometimento e doação não pode ser traduzido em qualquer valor financeiro.

Em um período em que a utopia parece morta, todos deveriam referenciar a memória de tantos brasileiros que sacrificaram suas vidas por um Brasil sem o capitalismo. É irônico que o mesmo Estado que guia a busca pela verdade tenha à frente do barco uma ex-combatente, mas no leme um Joaquim Levy e, na agricultura, Kátia Abreu ${ }^{6}$, ligados ao que de pior o liberalismo tem produzido no mundo, o que escancara os limites da busca por essa verdade.

Se não fosse tão danoso seria irônico que uma ex-combatente, que nega ter praticado de maneira violenta a retirada de recursos de bancos - podendo alegar tranquilamente que subtraía parte do tanto que o sistema retirava dos pobres e trabalhadores no dia a dia -, seja hoje alguém que dê condições para que esses mesmos bancos obtenham os maiores lucros da história do Brasil.

Da luta para a transformação do Brasil, que passava pela eliminação do capitalismo, a um esforço para fazer com que militares jamais saiam dos quartéis, ou para levar alguns deles à cadeia, parece-me que houve não apenas uma mudança significativa de perspectiva, mas o refazer de uma hegemonia tão eficiente que o próprio sistema permite que seus defensores do passado sejam levados ao tribunal, enquanto os que o ameaçavam naquele período hoje se tornam seus defensores.

A percepção das mudanças que a esquerda experimentou no Brasil pós-Golpe, permite identificar como a reificação do Golpe, enquanto acontecimento, oculta os termos em que a parte da própria esquerda altera sua percepção/inserção no mundo da política.

6 No momento da escrita, eram, respectivamente, ministros da Fazenda e da Agricultura. 
A violência não era, até o governo dos militares, o eixo de preocupações da esquerda, ou de parte dela. É possível acompanhar em dois números da revista Civilização Brasileira, que circularam em 1967, o esforço de parte da esquerda não de denunciar a violência, mas de buscar avançar em como se poderia abrir ou sinalizar a construção do socialismo, inclusive revendo procedimentos.

Nas publicações é assumido por intelectuais de esquerda o desafio de interpretar o que estava ocorrendo no prisma das lutas de classe, identificando no conhecimento produzido possibilidades de construção do socialismo. Nelas, aparece de maneira saudável um diálogo entre Caio Prado Júnior ${ }^{7} \mathrm{e}$ Assis Tavares ${ }^{8}$ sobre a repercussão do trabalho do primeiro: a Revolução Brasileira, estabelecendo profundas críticas sobre a interpretação e ação política do Partido Comunista no Brasil, na tentativa de construção do socialismo. Assis Tavares, defendendo as linhas mestras de interpretação e ação do partido contesta as teses de Caio Prado. A violência assumia um papel menor diante do imenso desafio de transformar uma ex-colônia portuguesa em uma nação socialista.

É possível identificar que a violência praticada e/ou sancionada pelo Estado é parte da sustentação do capitalismo e sua superação passa, necessariamente, pela superação da forma de Estado que o capitalismo sustenta.

O esforço em denunciar a violência do Golpe contra setores da esquerda ao se restringir à temporalidade do golpe, 1964/1985, despreza que essa violência, principalmente para o mundo dos trabalhadores, não começou em 1964, e tampouco parou em 1985. No mesmo caminho, ao restringir a ação do Estado a segmentos determinados, perde a oportunidade de identificar que

7 PRADO, Caio. Adendo à Revolução Brasileira. Civilização Brasileira, Rio de Janeiro, ano III, n. 14, p. 43-73, jul. 1967.

8 TAVARES, Assis (Pseudônimo de Marco Antônio Tavares Coelho). Caio Prado e a teoria da revolução brasileira. Civilização Brasileira, Rio de Janeiro, n. 11-12, p. 48-80, mar. 1967. 
aquela violência é parte de um mecanismo maior, que atingiu/ atinge índios, negros, pobres.

A violência no mundo capitalista e a que se pratica no comunismo na União Soviética foi parte de um debate em que se discutia em que termos políticas e em quais perspectivas de transformação essa violência se baseava.

Podemos acompanhar parte desse debate em Humanismo e terror: ensaio sobre o problema comunista, publicado no Brasil em 1968. Merleau-Ponty enfrenta o dilema da violência em um momento em que já se apresenta nos julgamentos de Moscou como o comunismo, para se afirmar na União Soviética, admitia o uso da violência na eliminação de opositores como Roubachof.

Os chamados processos de Moscou são usados como forma de propaganda contra o comunismo, inclusive na Europa. O autor reflete sobre a contradição entre o comunismo, que assume a violência como prática para a "solução do problema humano", e o liberalismo, que condena a violência, mas a legitima no dia a dia do funcionamento do capitalismo.

Discute-se, frequentemente, o comunismo opondo à mentira ou à astúcia o respeito à verdade, à violência, o respeito à lei, à propaganda, o respeito das consciências, enfim o realismo político, os valores liberais. Os comunistas respondem que, acobertados nos princípios liberais, a astúcia, a violência, a propaganda, o realismo sem princípio fazem, nas democracias, a substância da política estrangeira ou colonial e mesmo política social. O respeito à lei ou à liberdade serviu para justificar a repressão policial nas greves na América; serve hoje para justificar a repressão militar na Indochina ou na Palestina e o desenvolvimento do império americano no Oriente Médio. A civilização moral e material da Inglaterra supõe a exploração das colônias. A pureza dos princípios, não somente tolera, como ainda necessita de violências. Há, portanto, uma mistificação liberal. Consideradas na vida e na história, as idéias liberais formam sistema com essas violências constituindo, como dizia Marx, o "ponto de honra espiritualista", o "complemento solene", a "razão geral da consolação e de justificação". (MERLEAU-PONTY, 1968, p. 9). 
O autor não separa liberalismo e comunismo pela violência, que um nega pelo discurso e pratica como política de Estado, e que o segundo assume, no esforço de resolver o "problema humano". É possível observar que a violência, de qualquer tipo, por maior que seja o esforço para ocultá-la, jamais dissocia ação e revisão da ação de sua direção política, mantendo ou mudando o mundo em que nos estabelecemos.

No Brasil os termos dos debates são profundamente alterados de um período em que a esquerda luta pela destruição/superação de um Estado, enquanto suporte de uma sociedade em que o capital estrangula de maneira impiedosa o trabalho, para outro em que o Estado inclui, dentro de um discurso maior de inclusão social, o fato, readequando-o aos termos que sanciona o próprio Estado que indeniza, supostamente atendendo aos que foram mortos.

Thompson chama atenção para o fato de como acontecimentos violentos e sua expressão, observada nas estatísticas, não indicam por si só sua inserção em processos culturais, o que exige que eles sejam analisados, inclusive nas clivagens culturais.

Lidando especificamente com a violência, ele revela que:

a importância simbólica da violência - tanto faz que seja a violência do Estado e da lei ou a violência do protesto - não necessariamente possui uma correlação direta com quantidades. Cem pessoas podem perder a vida em um desastre natural e o fato não provocará nada além de piedade; um homem pode ser espancado até a morte numa delegacia policial e o fato dará origem a uma onda de protestos que irá transformar a política de uma nação. [...] nem o terror nem o contraterror revelam seu significado numa pesquisa puramente quantitativa, pois as quantidades devem ser vistas dentro de um contexto total, isso inclui o contexto simbólico, que atribui valores diferentes a tipos distintos de violência. (THOMPSON, 2001, p. 240-241).

Para o autor a violência, tanto na sua expressão física ou simbólica, não emerge purificada pelo grau de crueldade nem 
pela quantidade, estaria significada no "contexto simbólico, que atribui valores diferentes a tipos distintos de violência". No alerta de Thompson verificamos que o grande risco de uma memória que enclausura o passado em um tempo e de pessoas que ocultam intencionalidades políticas é abrir espaço para que os opositores executem o mesmo procedimento de forma inversa.

O renascer da direita no Brasil no mundo atual e sua chegada ao poder não indica meramente a vitória de um outro grupo, mas como o mesmo Estado agora pactua com um outro grupo. O esforço da esquerda em legitimar sua ação no presente, tentando purificar um tempo passado condenando os violentos que torturaram e mataram, a direita, hoje, com respaldo de grande parte da população, chama pelos militares para combater os violentos do presente que estariam saqueando a Petrobrás e tantas outras empresas públicas.

Por mais que não se queira refletir sobre tal fato, não é apenas a esquerda que procede a seu revisionismo no campo de forças do social; a direita também faz um acerto com seu passado e legitima sua ação no presente. No campo de embates da memória, violência é um termo escorregadio, visto que o argumento que a legitima hoje pode ser invertido: os violentos de uma época podem se tornar os redentores em outra.

O restringir a memória da violência do Estado em um tempo e circunscrita a um grupo específico, em qualquer critério que justifique esse grupo, não permite dimensionar a violência cotidiana do Estado, armada e/ou simbólica contra, principalmente, os mais pobres.

A brutalidade da Polícia Militar e do Exército em favelas do Rio de Janeiro e de São Paulo, a violência sistemática contra negros, índios e pobres que assistimos no dia a dia nas periferias de nossas cidades, não são desvios pessoais de agentes do Estado, mas uma pequena parte da grande violência que esses setores estão submetidos, como maneira de manter funcionando uma sociedade extremamente desigual. Segundo o relatório ${ }^{9}$ da

9 FORÇA policial brasileira é a que mais mata no mundo, diz relatório. Globo News. Disponível em: <http://glo.bo/1Nep53g>. Acesso em: 23 dez. 2015. 
Anistia Internacional, divulgado em 2015, a polícia brasileira é a que mais mata no mundo.

O desafio de passar de memórias coletivamente enclausuradas em marcos institucionalizados para o que Portelli identifica como memórias possíveis faz com que não apenas desamarremos o passado dos aprisionamentos, mas abramos o presente a novos horizontes.

Memórias possíveis não apenas permitem identificar como diversas possibilidades foram exercitadas/imaginadas, mas como projetos hegemônicos de grupos e/ou de instituições se apropriaram dessas versões e possibilidades, retirando-lhes os horizontes da transformação e da utopia.

Bem, a questão é que não creio muito em algo que se coloque como uma memória coletiva, porque não vejo onde está situada uma memória coletiva, a não ser nas atividades intelectuais de cada um dos indivíduos. Uma memória coletiva institucionalizada pode transformar-se nessas memórias hegemônicas muito fortes que estão consolidadas em arquivos oficiais e em monumentos, que me parecem importantes que existam. No entanto, o que vemos na História Oral é mais a memória que cada ser humano tem individualmente. Essa memória é um produto social, porque todos nós falamos um idioma, que é um produto social; nossa experiência é uma experiência social, mas não se pode submeter completamente a memória de nenhum indivíduo sob um marco de memória coletiva. Cada pessoa tem uma memória, de alguma forma, diferente de todas as demais. Então o que vemos, mais do que uma memória coletiva, é que há um horizonte de memórias possíveis. (PORTELLI, 2014, p. 201).

Lidando com história oral, o autor alerta para como diversas experiências/memórias podem ser organizadas em algo que, ao se tornar coletivo, pode dar vazão a grupos e instituições. Ao negar o modo como os indivíduos exercitam as possibilidades existentes no social, não apenas são negadas essas possibilidades, mas silenciado o seu exercício. 
A história oral, dentre outros registros, permite que versões organizadas em memórias alternativas às oficiais possam revelar não apenas novos significados do ocorrido, mas identificar como determinadas memórias foram/são silenciadas. Embora seja angustiante apresentar outras memórias considerando a possibilidade de estas serem entendidas como menosprezo a tantos que foram mortos, torturados e mutilados nos porões da ditadura, é preciso afirmar que elas estão sendo usadas no presente, em muitos casos, em um sentido inverso ao que essas pessoas defenderam e pelo que lutaram.

Em suas pesquisas, Portelli ${ }^{10}$ tem nos mostrado como a Itália - que teve sua construção pautada na ação dos comunistas que libertaram o país dos alemães e na luta pela democracia assistiu a um revisionismo extremado que permitiu que as bases da fundação moderna da nação fossem revistos, possibilitando que um fascista como Berlusconi ${ }^{11}$ assumisse o governo.

Para o autor, a esquerda não ter considerado memórias alternativas que celebravam a morte de parentes como um luto que não se diluía na ação do Estado e que foram/são apropriadas pela direita, que Ihes dá uma direção política, é um dos fatores que permitiram esse revisionismo.

O esforço de alargar as memórias possíveis de trabalhadores que experimentaram por outros ângulos a violência, requer repensar como esses trabalhadores comuns tem sido identificados dentro da própria esquerda.

Atribuir a estes personagens o papel de protagonismo político, tencionando suas memórias com os lugares em que viveram/ vivem e as condições das elaborações que procederam, permite emergir maneiras alternativas que aquele passado foi vivido e

10 Cf. PORTELLI, Alessandro. O massacre de Civitella Val di Chiana (Toscana, 29 de junho de 1944): mito e política, luto e senso comum. In: FERREIRA, Marieta de Moraes; AMADO, Janaína (Orgs). Usos e abusos da História Oral. 7. ed. Rio de Janeiro: Editora FGV, 2005. p. 103-130.

11 Sílvio Berlusconi governou a Itália com uma coalizão de direita nos períodos: 1994-1995; 2001-2006; 2008-2011. 
significado, permitindo construir não apenas interpretações para o tempo de hoje, mas estratégias políticas de intervenção neste tempo.

Edward Palmer Thompson ${ }^{12}$, ao estabelecer uma perspectiva em que as pessoas comuns são identificadas não como adorno ou como vítimas, mas pelo seu modo de viver, possibilita identificar processos de construção em que hegemonias são produzidas, problematizadas e refeitas.

Crítico de uma perspectiva em que pessoas comuns são atadas de maneira mecânica às oscilações do mercado, estabelece uma perspectiva em que só se tomam as pessoas comuns como protagonistas durante a Revolução Francesa, polemizando com a visão segundo a qual os pobres têm sua ação política atrelada à fome.

Segundo essa visão, dificilmente se pode tomar a gente comum como agente histórico antes da Revolução Francesa. Antes desse período, ela se intromete ocasional e espasmodicamente na cena histórica em períodos de repentina perturbação social. Essas intromissões são antes compulsivas que conscientes ou autoativadas: não passam de reações aos estímulos econômicos. Basta mencionar uma colheita malograda ou uma tendência de baixa no mercado, e todos os requisitos da explicação histórica são satisfeitos. (THOMPSON, 1998, p. 150).

O esforço de Thompson em identificar como a ação dos pobres não reproduz o impulso do estômago, mas revela momentos em que contradições ocultadas por hegemonias são postas à luz nestes momentos, levou a história social a uma nova direção.

No Brasil, nem a visão condescendente do espasmódico foi deferida aos pobres. Quando ausentes de instituições como as Ligas Camponesas, sindicatos e partidos, aparecem enquanto

12 THOMPSON, Edward Palmer. Costumes em comum: estudos sobre a cultura popular tradicional. São Paulo: Companhia das Letras, 1998. 
vítimas inertes do capitalismo ou de um período pré-capitalista, em que a efetivação do primeiro os redimiria e possibilitaria condições políticas para a existência de uma consciência que permitiria construir o socialismo.

Em um mecanismo complexo, em alguns momentos aos pobres são imputadas as causas de sua dominação.

A chegada de Thompson ao Brasil permitiu que historiadores, dentre eles, Déa Fenelon e Yara Aun Khoury, firmassem uma tradição desses estudos, pondo em destaque não como pessoas comuns sentem as grandes transformações, mas como estas se alimentam do mundo vivido por tais pessoas.

A intervenção aqui proposta se filia (sem a pretensão de se apropriar dela) a uma tradição no interior da historiografia que assumiu/assume o desafio de pensar a história como uma construção plural. Um percurso que, à esquerda, tem débitos consideráveis com a saudosa professora Déa Ribeiro Fenelon e com Yara Ahun Khoury, que avançou consideravelmente no esforço de identificar como todo processo histórico se constitui em projetos hegemônicos e disputados e como pessoas comuns os vivenciam de maneira diferenciada, produzindo memórias que nos permitem elucidar maneiras alternativas para se compor o enredo da história.

O cuidado na análise com as maneiras alternativas com que as pessoas comuns vivem e dão sentido ao vivido; pois, o ser social não apenas reproduz na consciência social o mundo vivido, mas nos dá a conhecer, por intermédio dos mecanismos da memória, enfrentamentos, derrotas e silenciamentos, já há algum tempo se tornou para os pesquisadores um campo interessante de percepção da construção, reconstrução e problematização dos processos hegemônicos. Confrontando análises e reflexões com o intuito de reafirmar, em um novo contexto, nossas percepções marxistas de perspectiva do social, essa temática tem surgido, para além de um novo espaço político, também com a perspectiva de intervenção, firmando a história não apenas no aspecto retrospectivo, mas prospectivo. 
Esse avanço é significativo e percebido no acúmulo de pesquisas e debates realizados sobre memória, revelando-se em entrevistas produzidas com pessoas comuns ou grupos não institucionalizados. Sob a perspectiva da valorização das posições e lembranças de pessoas, grupos e instituições ligadas diretamente a um acontecimento, avançamos na identificação de que memórias alternativas não apenas nos distanciam do acontecimento, mas o colocam como possibilidades não apenas da preservação do ocorrido, dando-lhe uma direção política, permitindo compreender como ele é validado por determinados projetos e posições que se legitimam como parte indissociável da construção de projetos hegemônicos.

O avanço que obtivemos com a leitura de Thompson e sua influência nas pesquisas permitiu que nós, historiadores, indagássemos sobre espaços políticos ocupados por pessoas comuns, possíveis de identificar processos de construção histórica em diversos tempos e lugares. O avanço na percepção das diversas memórias que compõem a constituição de hegemonias não foi seguido do avanço em direção a outras histórias.

Fenelon e outros nos chamam a atenção para o avanço em relação ao reconhecimento das muitas memórias e, ao mesmo tempo, para o nosso recuo na construção de outras histórias.

Num primeiro plano, colocava-se uma inquietação que já vínhamos há algum tempo explicitando em nossas conversas: o fato de avançarmos mais na discussão sobre memória social, ou seja, quando sinalizamos para "muitas memórias" assumimos lidar com memória no plural. O problema relaciona-se às "outras histórias". Lendo os nossos trabalhos, as "memórias" sempre aparecem no plural, no entanto, quase sempre "História" aparece no singular. É muito difícil colocar o "s" na história com "H". Este parece ser um dos desafios a enfrentar aqui: assumir que o "s" do plural não está no subtítulo para mera composição de simetria. (FENELON; CRUZ; PEIXOTO, 2004, p. 5-6.)

Assumindo o desafio proposto pelas autoras, identifico que a pesquisa que desenvolvemos e abordou o golpe de 1964, 
obrigou-nos a sair dos marcos consagrados e a visualizar uma outra dinâmica do processo histórico.

Nas pesquisas realizadas durante o mestrado e o doutorado não era interesse central pensar o golpe de 1964. Enquanto no mestrado interessamo-nos por identificar uma memória constituída por trabalhadores braçais alternativa à memória de progresso e desenvolvimento ferroviário, no doutorado buscamos identificar as redefinições coetâneas de campo e cidade submissas ao refazerse do mundo do trabalho e dos trabalhadores.

Em alguns momentos da investigação, na produção de entrevistas, deparamo-nos com uma expressão comum a muitos entrevistados. Quando indagados sobre como foi o período de 1964, muitos afirmaram que: "naquele tempo havia muita violência”. Essas respostas remeteram-me ao período reafirmando o marco, compreendendo-o enquanto período em que todos os trabalhadores teriam sido torturados.

A ligação automática que inicialmente procedi da fala dos entrevistados ("naquele tempo havia muita violência") e o marco consagrado por instituições e partidos que legitima 1964 como marco de memória deveu-se em parte ao esforço do Partido Comunista, que afirma ter sido muito forte a atuação na região Sudeste, principalmente em Goiandira e Catalão.

Goiandira surge nesse cenário como um local onde teria havido forte agitação política em prol do partido.

Enfrentamos um impasse em que o marco das instituições e o das pessoas comuns me levavam a 1964, mas que o olhar empírico não comprovava o que aparentemente se apresentava. Esse impasse e uma observação feita pela professora Yara Aun Khoury, em um encontro realizado em Uberlândia, pressionaramme a rever os procedimentos que adotava na análise das memórias pesquisadas.

Nesse esforço, resolvemos incorporar à pesquisa um outro tipo de registro, o processo-crime, na tentativa de verificar como eram atingidas pelos militares as ações subversivas.

Um processo-crime permitiu que fossem mudados os procedimentos. O contexto do processo é significativo em 
demonstrar como o momento de alteração de uma ordem pode permitir que conflitos ocultados no quotidiano possam emergir.

O contexto do golpe militar, na região Sudeste, fez parte de um processo em que a Companhia de Engenharia e Combate, com sede na cidade de Ipameri, assumiu a função policial nas cidades fragilizando a estrutura que funcionava e passava pelo controle dos políticos.

Em Goiandira, o processo pesquisado inicia com um ofício enviado, pelo comandante do exército, ao delegado da cidade, Prudêncio Quirino Garcia, até então submisso à ação dos políticos locais, para que este forneça ao exército nomes de comunistas que poderiam estar envolvidos em ações de subversão.

O pedido da lista dos nomes foi significativo, considerando que permitiu ao delegado, que até o momento parecia estar à mercê dos políticos locais, preparar uma lista em que a motivação de estar ligado ao Partido Comunista ocultava conflitos locais observados na cidade.

A lista fornecida citava personagens da política local, alguns vereadores, dando os pormenores de um acerto do delegado com seus desafetos.

Intimados pelo exército para se explicarem, em razão da denúncia de estarem ligados ao Partido Comunista, o vereador Waldivino José Cardoso, um dos acusados, ao ser ouvido expôs, de maneira pormenorizada, as ações do delegado na cidade para desqualificá-lo.

Que o declarante sabe de diversas arbitrariedades praticadas pelo delegado municipal de polícia de Goiandira, uma das quais, no próximo mês passado, não recordando precisamente o depoente, que nesta cidade esta autoridade apreendeu dois revólveres de um rapaz, filho do Sr. Salomão Lorenço residente nesta cidade, deteve-o, e prometera soltá-lo, somente com o pagamento da importância de CR \$ 12.000,00; diz o depoente, que esta importância fora paga ao Delegado Municipal de Goiandira, após o rapaz filho de Salomão Lorenço, ser posto em liberdade, após uma noite de xadrez que sabe de uma outra arbitrariedade da mesma autoridade, desta 
feita, com um rapaz filho de Goiandira, que fora implacavelmente espancado, e por este motivo, o rapaz espancado, mudara para a cidade de Araguari que não sabe o motivo do espancamento mas diz o declarante, que o delegado municipal de polícia apreendera a arma, e nas palavras do rapaz espancado tomaram-lhe a importância de CR $\$ 20.000,00$, cujo rapaz é conhecido pelo nome de José Barba que foi no ano de 1962 ou 1963, não podendo precisar exatamente a data que aconteceu o espancamento, seguido de prisão de José Barba, residente atualmente na cidade de Araguari; que por ouvir dizer, sabe o depoente, que na mesma época que ocorrera o fato do rapaz (ilegível) dito pelo farmacêutico Calicanto Querido, residente nesta cidade, haver o Delegado Municipal de Polícia, cortado de canivete, a língua de um menor de cor preta, sem haver contudo, perdido parte deste membro, e que fora o mesmo farmacêutico informante, que administrou os curativos do corte da língua do menor, diz o depoente, que ainda no ano de 1962, 1963, não recordando a data nem os nomes, o delegado municipal de Polícia de Goiandira prendera Nelson Marques, que sofrera na prisão espancamentos, pagamento em dinheiro para ser posto em liberdade e que ainda, diz o depoente, esta mesma autoridade mantinha relações sexuais com a filha de Nelson, e este, aborrecido com o fato, mudara para a cidade de Catalão; que na ocasião que fora descoberto, tornado público, o defloramento da filha de Nelson Marques, sendo o autor possível, o Delegado Municipal de Polícia, é por esta acusado um suspeito, conhecido pelo nome de José Tutinha, que sofrera na prisão por dois dias, sendo posteriormente posto em liberdade, sem saber o depoente, se houve a abertura de inquérito; ainda na mesma época, ou seja, entre 1962 e 1963, fora do perímetro desta cidade, um rapaz, Eurípedes Pinto Calaso, residente nesta cidade dera um tiro de garrucha, acontecendo com isto, a autoridade mandou prende-lo, tomaram a arma, e exigiram o pagamento da importância de $C R \$ 2.000,00$, alegando a multa do disparo da arma, e que a mãe de Eurípedes, pessoa pobre, não querendo ver o filho preso, procura o delegado, alegando não possuir aquela importância, sendo que o mesmo, empresta os $C \$ 2.000,00$, à mãe do rapaz, 
ficando assim quitada a importância exigida para multa do disparo da arma de fogo; que o delegado municipal de Polícia de Goiandira, persistindo em suas arbitrariedades, manda prender um indivíduo doente, residente em Catalão, que o indivíduo Lázaro Albino Vaz é duramente espancado; diz o depoente, que por ouvir dizer, sendo o informante conhecido por Tito, residente nesta cidade, que numa ocasião estava surgindo nesta cidade, diversos e constante roubos, o filho do Delegado Municipal de Polícia, é por esta espancado, ignorando o declarante o motivo, mas que na fuga do filho do Delegado, saltando, diz em alta voz: "Que os roubos que estavam acontecendo nesta cidade, era o autor o seu próprio pai" (GOIÁS. Processo n. 26/66, Sala de despejo da Comarca de Goiandira.)

O embate entre delegado e vereadores prossegue, o delegado os acusa de atividades subversivas, anexando fotos de pichações que surgem na cidade enaltecendo o partido comunista. Os vereadores, em sua defesa, afirmam que o delegado é o responsável pelas pichações e que está tentando incriminá-los.

O primeiro esforço de interpretação do documento exige que não se proceda a um início validado pela presença de duas instituições, a militar e o partido de esquerda. Nesse caso, em específico, as forças envolvidas não se articulam em torno da instituição militar, considerando-se que o protagonista a quem é atribuída a direção do processo é subdelegado de polícia, indicado por políticos para o cargo.

Não há também evidências de os políticos estarem diretamente vinculados ao partido comunista. Percebemos que um determinado vocabulário é usado como maneira de se nominar a realidade local com termos que a articulam a questões mais amplas que permeiam o cenário nacional.

Para além do posicionamento de duas instituições, é possível identificar uma fratura entre setores da mesma elite. Essa fratura expõe os mecanismos de controle e ação da elite na cidade, emergindo assim de onde ela define a ação do poder, o mundo dos trabalhadores. 
O golpe de 1964 permite, em Goiandira, identificar a disputa política, entre setores de uma mesma elite, pelo controle da cidade, possibilitando-nos conhecer mecanismos de ação, desta mesma elite que, em períodos sem grandes alterações públicas, possam passar despercebidas.

O registro ocorre em um momento significativo em que há uma redefinição do campo e da cidade, com mudanças atreladas a uma nova maneira de trabalhar e produzir. No doutorado, avançamos na perspectiva de compreender que a crise de trabalho no campo estava firmada em um movimento em que sua construção estabelecia os limites de sua reprodução.

Em linhas gerais, o fazendeiro, ao contratar algum trabalhador, deveria fornecer a ele, no primeiro ano de trabalho, alimentação e moradia, geralmente um rancho. Esse aspecto implicava que a fazenda tivesse um armazém onde esses mantimentos deveriam ser guardados para se manter uma mão de obra regular, em uma economia ainda com pouco grau de monetarização. Esse elemento não nos levou a identificar como tal aspecto estava ligado plenamente à monetarização posterior, mas como se articulava com um certo grau de organicidade, inclusive cultural.

Há um processo dialético em que as próprias condições da produção estabelecem os limites da reprodução. Na medida em que a manutenção da força de trabalho exige que haja depósito de alimentos, e este exige, na sua produção, uma mão de obra considerável, há um entrave, pois, a partir do segundo ano, o trabalhador produz, sendo uma parte dessa produção destinada ao fazendeiro e outra ao seu próprio consumo.

Aspectos como o aumento da população, tanto proprietária quanto trabalhadora, pressionam para que ocorram dificuldades no ritmo da produção. Esses limites fazem com que as formas de produção sejam tensionadas, havendo uma saída de trabalhadores das fazendas para as cidades, fato ocorrido em Goiandira.

Para além do movimento da saída do campo para a cidade, presenciamos um instante em que ambos (campo e cidade), articulados pelo mundo do trabalho e dos trabalhadores, são redefinidos, inclusive em suas estruturas burocráticas. 
O trabalho das pessoas no campo fazia com que naquele espaço fossem resolvidas todas as diversas transgressões que ocorriam e o fazendeiro, como o juiz-quarteirão, resolvia diretamente a questão ou acompanhava o trabalhador nas demandas ocorridas na cidade.

$O$ registro criminal permite identificar um instante em que a redefinição de vida na cidade fez com que não apenas os trabalhadores se confrontassem com outros poderes, mas com que os próprios poderes lidassem com situações com as quais não lidavam antes.

Nos limites a que nos dispomos a chegar neste artigo, entendemos que esse exercício de leitura e interpretação nos permite, além de destravar a memória das amarras, entender em sua multiplicidade um processo. Tal processo nos leva a investigar como os trabalhadores, ao se reconstituírem na cidade, obrigavam a uma rearticulação dos poderes que a governavam, conduzindonos de outras memórias a outras histórias. Essas outras histórias se esquivam do caminho do progresso do urbano e como que antecedem e redimem os trabalhadores pobres do campo.

Aqui sinalizamos uma outra perspectiva em que 1964, em uma pequena cidade de Goiás, pode ser tomada como a experiência de trabalhadores que, mesmo sem envolvimento político direto, se confrontam com o Estado e seus mecanismos, em um instante em que a elite precisa redefinir os termos do próprio controle. Alargando a compreensão da memória percebemos que a própria elite precisa redefinir os termos do controle, na medida em que a presença de pobres vindos do campo altera a ordem econômica e moral da cidade.

Uma busca por desnudar mecanismos de memórias poderosas precisa se constituir em um desafio e em um estímulo para nossas atividades, quaisquer que sejam elas, revelando a ação dos poderes em seus aspectos sutis, poderes esses que, ao se realimentarem e serem ressignificados, negam no passado um doce a uma criança e, talvez de forma mais violenta, negam à classe social, da qual essa criança é representante, o direito às suas memórias. 
Sem a devida atenção à crítica, a violência, desprovida de suas direções políticas, pode dar ao Estado, avalista do processo de espoliação dos trabalhadores de ontem e hoje, o papel de redentor destes.

\section{Referências Bibliográficas}

ALMEIDA, Paulo Roberto de; KHOURY, Yara Aun. História oral e memórias: entrevista com Alessandro Portelli. História \& Perspectivas, Uberlândia, n. 50, jan./jun. 2014. Disponível em: <http://www.seer.ufu.br/ index.php/historiaperspectivas/article/viewFile/27504/15080> . Acesso em :16 jan. 2016.

BRASIL. Lei n. 12528, de 18 de novembro de 2011. Disponível em: <http://www.planalto.gov.br/ccivil_03/_ato2011-2014/2011/lei//12528. htm>. Acesso em: 23 nov. 2015.

CALIL, Gilberto Grassi; LEMOS, Renato Luís do Couto Neto e. Introdução ao dossiê. Tempos Históricos, v. 18, n. 1, p. 10-12, 2014.

FENELON, Déa Ribeiro; CRUZ, Heloísa de Faria; PEIXOTO, Maria do Rosário Cunha. Muitas memórias, outras histórias. In: FENELON, Déa Ribeiro et al (Orgs.). Muitas memórias, outras histórias. São Paulo: Olho d’Água, 2004. p. 5-13.

KHOURY, Yara Aun. Narrativas orais na investigação da história social. Projeto História, São Paulo, n. 22, p. 79-103, jun. 2001.

MELO, Demian Bezerra de; HOEVELER, Rejane Carolina. Muito além da conspiração: uma reavaliação crítica da obra de René Dreifuss. Tempos Históricos, Marechal Cândido Rondon, v. 18, n. 1, p. 13-43, 2014.

PONTY, Maurice Merleau. Humanismo e terror: ensaio sobre o problema comunista. Rio de Janeiro: Tempo Brasileiro, 1968. 
THOMPSON, Edward Palmer. A economia moral da multidão inglesa no século XVIII. In: _. Costumes em comum: estudos sobre a cultura popular tradicional. São Paulo: Companhia das Letras, 1998. p. 150-202.

THOMPSON, Edward Palmer. Folclore, antropologia e história social. In: _. As peculiaridades dos ingleses e outros artigos. Campinas: Editora da Unicamp, 2001. p. 227-267.

Recebido em maio de 2016. Aprovado em fevereiro de 2017. 